\title{
Bacillus marismortui sp. nov., a new moderately halophilic species from the Dead Sea
}

\author{
David R. Arahal, ${ }^{1}$ M. Carmen Márquez, ${ }^{1}$ Benjamin E. Volcani, ${ }^{2} \S$ \\ Karl H. Schleifer ${ }^{3}$ and Antonio Ventosa ${ }^{1}$
}

\begin{abstract}
Author for correspondence: Antonio Ventosa. Tel: +34954 556 765. Fax: + 34954628162. e-mail: ventosa@cica.es
\end{abstract}

\footnotetext{
1 Departamento de Microbiología y Parasitología, Facultad de Farmacia, Universidad de Sevilla, Seville, Spain

2 Marine Biology Research Division, Scripps Institution of Oceanography, University of California, San Diego, La Jolla, CA, USA

3 Lehrstuhl für Mikrobiologie, Technische Universität München, Munich, Germany
}

\begin{abstract}
A group of 91 moderately halophilic, Gram-positive, rod-shaped strains were isolated from enrichments prepared from Dead Sea water samples collected 57 years ago. These strains were examined for 117 morphological, physiological, biochemical, nutritional and antibiotic susceptibility characteristics. All strains formed endospores and were motile, strictly aerobic and positive for catalase and oxidase. They grew in media containing 5-25\% (w/v) total salts, showing optimal growth at $10 \%(w / v)$. Eighteen strains were chosen as representative isolates and were studied in more detail. All these strains had mesodiaminopimelic acid in the cell wall and a DNA G+C content of 39.0-42.8 mol\%; they constitute a group with levels of DNA-DNA similarity of $70-100 \%$. The sequences of the 16S rRNA genes of three representative strains (strains 123', 557 and 832 ) were almost identical (99.9\%), and placed the strains in the low $G+C$ content Gram-positive bacteria. On the basis of their features, these isolates should be regarded as members of a new species of the genus Bacillus, for which the name Bacillus marismortui sp. nov. is proposed. The type strain is

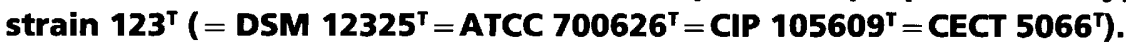

Keywords: Bacillus marismortui, taxonomy, DNA-DNA similarity, cell wall type, $16 \mathrm{~S}$ rRNA sequence

\section{INTRODUCTION}

Studies on the microbiology of the Dead Sea have demonstrated the presence of a variety of microorganisms adapted to the high salt concentration in the lake: protozoa, unicellular algae, cyanobacteria, and aerobic and anaerobic chemo-organotrophic prokaryotes (Javor, 1989; Ventosa et al., 1999). Among the aerobic prokaryotes, the majority of the isolates from the Dead Sea belong to the domain Archaea and are placed in the family Halobacteriaceae (Oren, 1993). On the other hand, in the domain Bacteria there have been a few reports about Gram-negative, moderately halophilic species (Oren, 1988). In contrast, there has been no description of aerobic, Gram-positive, moderately halophilic bacteria.

Abbreviations: $S_{j}$, Jaccard coefficient; UPGMA, unweighted pair group method with averages.

The EMBL accession number for the $16 \mathrm{~S}$ rRNA gene sequence of strain $123^{\top}$ is AJ009793.

§Deceased 6 February 1999.
In this study, a group of $91 \mathrm{Gram}$-positive, moderately halophilic, endospore-forming rods was isolated from enrichments obtained from Dead Sea water samples used by Volcani in 1936 and kept by him for more than 50 years in closed bottles. In a recent study, it has been shown that extremely halophilic archaea belonging to the genera Halobacterium, Haloarcula and Haloferax could still be isolated from these samples (Arahal et al., 1996). The strains isolated in the present study were characterized phenotypically, as well as with respect to their DNA base composition, levels of DNA-DNA similarity and cell wall composition. Three representative strains were selected for phylogenetic analysis of their 16S rRNA gene sequences. Our results suggest that these strains may represent a new species of the genus Bacillus, for which the name Bacillus marismortui sp. nov. is proposed.

\section{METHODS}

Strain isolation and culture conditions. The source of our isolates was seven enrichments obtained from water samples taken in 1936 by B. E. Volcani at surface level in the 
Table 1. DNA $G+C$ contents and levels of DNA-DNA relatedness for some strains of Bacillus marismortui and related genera

DNA similarities equal to or greater than $70 \%$ are given in bold.

\begin{tabular}{|c|c|c|c|c|}
\hline \multirow[t]{2}{*}{ Source of unlabelled DNA* } & \multirow[t]{2}{*}{$\begin{array}{c}G+C \\
\text { content } \\
(\operatorname{mol} \%)\end{array}$} & \multicolumn{3}{|c|}{$\begin{array}{c}\text { Homology (\%) with } \\
{ }^{3} \mathrm{H}-\text { labelled } \\
\text { DNA from strain: }\end{array}$} \\
\hline & & $123^{\mathrm{T}}$ & 557 & 832 \\
\hline \multicolumn{5}{|l|}{ Bacillus marismortui strains } \\
\hline 104 & $40 \cdot 9$ & 91 & 96 & 99 \\
\hline 114 & $40 \cdot 1$ & 91 & 88 & 86 \\
\hline 116 & $42 \cdot 4$ & 97 & 83 & 95 \\
\hline 120 & $42 \cdot 0$ & 91 & 91 & 88 \\
\hline $123^{\mathrm{T}}$ & $40 \cdot 7$ & 100 & 80 & 85 \\
\hline 135 & $42 \cdot 4$ & 95 & 93 & 83 \\
\hline 511 & $40 \cdot 1$ & 98 & 93 & 74 \\
\hline 517 & $39 \cdot 3$ & 89 & 96 & 79 \\
\hline 526 & $40 \cdot 5$ & 95 & 99 & 78 \\
\hline 532 & $40 \cdot 1$ & 95 & 92 & 97 \\
\hline 539 & $40 \cdot 1$ & 98 & 100 & 91 \\
\hline 544 & $39 \cdot 9$ & 97 & 98 & 97 \\
\hline 550 & $40 \cdot 1$ & 90 & 84 & 85 \\
\hline 557 & $42 \cdot 8$ & 87 & 75 & 100 \\
\hline 720 & $40 \cdot 7$ & 92 & 96 & 79 \\
\hline 811 & $41 \cdot 7$ & 93 & 86 & 93 \\
\hline 821 & $42 \cdot 2$ & 97 & 93 & 84 \\
\hline 832 & $39 \cdot 0$ & 72 & 100 & 70 \\
\hline Bacillus alcalophilus ATCC $27647^{\mathrm{T}}$ & $47 \cdot 0 \dagger$ & 0 & 0 & 10 \\
\hline Bacillus dipsosauri DSM $11125^{\mathrm{T}}$ & $40 \cdot 1$ & 11 & 8 & 10 \\
\hline Bacillus globisporus ATCC $23301^{\mathrm{T}}$ & $49 \cdot 0 \dagger$ & 27 & 7 & 12 \\
\hline Bacillus halophilus ATCC $49085^{\mathrm{T}}$ & $50 \cdot 8$ & 31 & 20 & 25 \\
\hline Bacillus marinus ATCC $29841^{\mathrm{T}}$ & $37 \cdot 6+$ & 0 & 0 & 6 \\
\hline Bacillus salexigens DSM $11483^{\mathrm{T}}$ & $39 \cdot 5 \dagger$ & 41 & 41 & 45 \\
\hline Halobacillus halophilus DSM $2266^{\mathrm{T}}$ & $40 \cdot 8 \dagger$ & 15 & 0 & 18 \\
\hline Halobacillus litoralis DSM $10405^{\mathrm{T}}$ & $42 \cdot 0 \dagger$ & 19 & 16 & 18 \\
\hline Halobacillus trueperi DSM $10404^{\mathrm{T}}$ & $43 \cdot 0 \dagger$ & 34 & 44 & 45 \\
\hline Paenibacillus polymyxa DSM $36^{\mathrm{T}}$ & $44 \cdot 3 \dagger$ & 19 & 27 & 18 \\
\hline Virgibacillus pantothenticus DSM $26^{\mathrm{T}}$ & $36.9+$ & 33 & 28 & 30 \\
\hline
\end{tabular}

* ATCC, American Type Culture Collection; DSM, Deutsche Sammlung von Mikroorganismen und Zellkulturen.

† Data from Garabito et al. (1997), Fahmy et al. (1985) and Spring et al. (1996).

Northern basin of the Dead Sea by sampling at different locations close to the mouth of the Jordan river (Volcani, 1936, 1940). The enrichments, prepared with Dead Sea water plus $1.0 \%(\mathrm{w} / \mathrm{v})$ peptone, were kept in closed $500 \mathrm{ml}$ bottles under sterile conditions and stored in the dark in a dry place at $18-20^{\circ} \mathrm{C}$. These enrichments remained unopened over the entire storage period. Inocula were removed in 1993 from the bottles under sterile conditions. Several isolation media were used with various total salt concentrations and compositions. SW-10 medium (Nieto et al., 1989) contained a final salt concentration of about $10 \%(\mathrm{w} / \mathrm{v})$ and $0.5 \%(\mathrm{w} / \mathrm{v})$ yeast extract (Difco). HM medium (Ventosa et al., 1982) contained a balanced mixture of salts, giving a final concentration of about $18 \%(\mathrm{w} / \mathrm{v})$, and was supplemented with $1 \%(\mathrm{w} / \mathrm{v})$ yeast extract (Difco), $0.5 \%(\mathrm{w} / \mathrm{v})$ proteose peptone no. 3 (Difco) and $0.1 \%(\mathrm{w} / \mathrm{v})$ glucose. The last medium used, designated $\mathrm{M} 4$, contained $(\mathrm{w} / \mathrm{v}): 10 \cdot 3 \%$ $\mathrm{NaCl}, 1.8 \% \mathrm{MgSO}_{4} .7 \mathrm{H}_{2} \mathrm{O}, 0.025 \% \mathrm{CaCl}_{2} .2 \mathrm{H}_{2} \mathrm{O}, 0.019$ $\mathrm{KCl}$ and $0.05 \%$ peptone (Difco). The $\mathrm{pH}$ was always adjusted to $7 \cdot 2$. Cultures were incubated at $37^{\circ} \mathrm{C}$ in an orbital shaker (New Brunswick Scientific) at 200 strokes $\min ^{-1}$. For the phenotypic characterization studies, the following reference strains were used: Bacillus alcalophilus ATCC $27647^{\mathrm{T}}$; Bacillus badius ATCC 14574 ${ }^{\mathrm{T}}$; Bacillus circulans ATCC 4513 ${ }^{\mathrm{T}}$; Bacillus coagulans ATCC $7050^{\mathrm{T}}$; Bacillus globisporus ATCC $23301^{\mathrm{T}}$; Bacillus halophilus ATCC 49085 ${ }^{\mathrm{T}}$; Bacillus insolitus ATCC 23299 ; Bacillus licheniformis ATCC $14580^{\mathrm{T}}$; Bacillus marinus ATCC $29841^{\mathrm{T}}$; Bacillus pallidus DSM $3670^{\mathrm{T}}$; Bacillus pumilus ATCC $7061^{\mathrm{T}}$; Bacillus salexigens DSM $11483^{\mathrm{T}}$; Bacillus smithii DSM 
Table 2. Phenotypic characteristics of the 91 isolates of Bacillus marismortui and the type strain of this species

All strains were strictly aerobic, grew in the presence of $5-20 \%(\mathrm{w} / \mathrm{v})$ salts, at $\mathrm{pH} 6 \cdot 5-8.0$ and at $15-50^{\circ} \mathrm{C}$. They were positive for catalase and negative for indole and phenylalanine deaminase. They did not produce acid from Darabinose, D-galactose or D-xylose and they did not hydrolyse Tween 80 . They utilized maltose, D-mannose and pyruvate but lactate was not utilized. They were susceptible to erythromycin $(15 \mu \mathrm{g})$ and resistant to nalidixic acid $(30 \mu \mathrm{g})$ and neomycin $(30 \mu \mathrm{g})$.

\begin{tabular}{|c|c|c|}
\hline Character & $\begin{array}{l}\text { No. of } \\
\text { strains } \\
\text { positive }\end{array}$ & $\begin{array}{c}\text { Bacillus } \\
\text { marismortui } \\
\text { strain } 123^{\mathrm{T}}\end{array}$ \\
\hline Terminal spores & 67 & + \\
\hline Subterminal spores & 24 & + \\
\hline Sporangium swollen & 78 & + \\
\hline \multicolumn{3}{|c|}{ Growth in salts at $(\%, w / v)$ : } \\
\hline 0.9 & 13 & - \\
\hline 3 & 44 & + \\
\hline 25 & 45 & - \\
\hline Growth at $55^{\circ} \mathrm{C}$ & 3 & - \\
\hline \multicolumn{3}{|l|}{ Growth at $\mathrm{pH}$ : } \\
\hline $5 \cdot 5$ & 6 & - \\
\hline $6 \cdot 0$ & 87 & + \\
\hline $8 \cdot 5$ & 87 & + \\
\hline $9 \cdot 0$ & 77 & - \\
\hline $9 \cdot 5$ & 39 & - \\
\hline \multicolumn{3}{|l|}{ Hydrolysis of: } \\
\hline Casein & 58 & + \\
\hline Gelatin & 87 & + \\
\hline Starch & 3 & - \\
\hline DNase & 87 & + \\
\hline Phosphatase & 83 & + \\
\hline \multicolumn{3}{|l|}{ Acid production from: } \\
\hline D-Fructose & 89 & + \\
\hline D-Glucose & 89 & + \\
\hline Glycerol & 88 & + \\
\hline Lactose & 4 & - \\
\hline Maltose & 88 & + \\
\hline D-Mannitol & 4 & - \\
\hline Sucrose & 5 & - \\
\hline D-Trehalose & 7 & - \\
\hline Methyl red & 79 & + \\
\hline Voges-Proskauer & 6 & - \\
\hline Nitrate reduction & 89 & + \\
\hline Nitrite reduction & 31 & - \\
\hline Citrate utilization & 18 & - \\
\hline $\mathrm{H}_{2} \mathrm{~S}$ production & 22 & + \\
\hline Arginine dehydrolase & 5 & - \\
\hline Urease & 80 & + \\
\hline \multicolumn{3}{|l|}{ Utilization of: } \\
\hline D-Arabinose & 24 & - \\
\hline D-Cellobiose & 22 & + \\
\hline D-Fructose & 85 & + \\
\hline D-Galactose & 17 & + \\
\hline D-Glucose & 18 & + \\
\hline Inulin & 42 & + \\
\hline
\end{tabular}

Table 2 (cont.)

\begin{tabular}{|lcc|}
\hline Character & $\begin{array}{c}\text { No. of } \\
\text { strains } \\
\text { positive }\end{array}$ & $\begin{array}{c}\text { Bacillus } \\
\text { marismortui } \\
\text { strain 123 }\end{array}$ \\
\hline Lactose & 14 & + \\
D-Raffinose & 87 & + \\
D-Rhamnose & 62 & + \\
D-Ribose & 5 & - \\
Salicin & 27 & - \\
Starch & 31 & - \\
Sucrose & 7 & - \\
D-Trehalose & 3 & - \\
D-Xylose & 4 & - \\
Glycerol & 4 & - \\
myo-Inositol & 18 & - \\
D-Mannitol & 59 & - \\
D-Sorbitol & 15 & - \\
Acetate & 21 & - \\
Butyrate & 10 & - \\
Citrate & 19 & - \\
Fumarate & 22 & - \\
L-Glutamate & 30 & - \\
Hippurate & 23 & - \\
Malate & 14 & - \\
Propionate & 10 & + \\
Succinate & 68 & + \\
L-Alanine & 16 & - \\
DL-Arginine & 5 & - \\
L-Asparagine & 29 & - \\
L-Aspartic acid & 89 & + \\
L-Glutamine & 8 & - \\
L-Isoleucine & 4 & - \\
L-Leucine & 15 & - \\
L-Ornithine & 14 & - \\
L-Phenylalanine & 57 & + \\
L-Proline & 19 & - \\
L-Serine & 17 & - \\
L-Threonine & 10 & - \\
Susceptibility to: & 43 & + \\
Chloramphenicol $(30 \mu g)$ & 22 & - \\
Novobiocin $(30 \mu \mathrm{g})$ & 89 & + \\
Penicillin G $(10 \mathrm{U})$ & & - \\
Rifampin $(5 \mu \mathrm{g})$ & & - \\
Streptomycin $(10 \mu \mathrm{g})$ & - & - \\
Tetracycline $(30 \mu \mathrm{g})$ & & - \\
\hline
\end{tabular}

$4216^{\mathrm{T}}$; Bacillus subtilis ATCC $6051^{\mathrm{T}}$; and Virgibacillus pantothenticus ATCC $14576^{\mathrm{T}}$. For the DNA-DNA hybridization studies, the reference strains shown in Table 1 were used. The recommended media and culture conditions were used to grow these organisms.

Phenotypic characterization. Tests for 117 characteristics, including morphological, cultural, physiological, biochemical, nutritional and antibiotic susceptibility features, were carried out (Table 2). All test procedures have been described previously (García et al., 1987; Quesada et al., 1984; Ventosa 
Table 3. Bacterial strains and accession numbers of sequences used in 16S rRNA analysis

\begin{tabular}{|c|c|c|}
\hline Species & Strain* & $\begin{array}{c}\text { EMBL } \\
\text { accession } \\
\text { no. }\end{array}$ \\
\hline Aneurinibacillus aneurinolyticus & NCIMB $10056^{\mathrm{T}}$ & X60645 \\
\hline Bacillus alcalophilus & $\operatorname{ATCC} 27647^{\mathrm{T}}$ & X60603 \\
\hline Bacillus badius & ATCC $14574^{\mathrm{T}}$ & D78310 \\
\hline Bacillus cereus & ATCC $14579^{\mathrm{T}}$ & X55060 \\
\hline Bacillus circulans & NCDO $1775^{\mathrm{T}}$ & X60613 \\
\hline Bacillus coagulans & NCDO $1761^{\mathrm{T}}$ & X60614 \\
\hline Bacillus cohnii & DSM $6307^{\mathrm{T}}$ & $X 76437$ \\
\hline Bacillus dipsosauri & NCFB $3027^{\mathrm{T}}$ & X82436 \\
\hline Bacillus globisporus & NCIMB $11434^{\mathrm{T}}$ & X60644 \\
\hline Bacillus insolitus & DSM $5^{\mathrm{T}}$ & $\mathrm{X} 60642$ \\
\hline Bacillus licheniformis & NCDO $1772^{\mathrm{T}}$ & X60623 \\
\hline Bacillus megaterium & ATCC $14581^{\mathrm{T}}$ & X60629 \\
\hline Bacillus pallidus & DSM $3670^{\mathrm{T}}$ & Z26930 \\
\hline Bacillus pasteurii & NCIMB $8841^{\mathrm{T}}$ & X60631 \\
\hline Bacillus pumilus & NCDO $1776^{\mathrm{T}}$ & X60637 \\
\hline Bacillus salexigens & ATCC $700290^{\mathrm{T}}$ & Y11603 \\
\hline Bacillus smithii & DSM $4216^{\mathrm{T}}$ & Z26935 \\
\hline Bacillus stearothermophilus & ATCC $12980^{\mathrm{T}}$ & X60640 \\
\hline Bacillus subtilis & NCDO $1769^{\mathrm{T}}$ & X60646 \\
\hline Brevibacillus brevis & NCIMB $9372^{\mathrm{T}}$ & X60612 \\
\hline Brevibacillus laterosporus & NCDO $1763^{\mathrm{T}}$ & X60620 \\
\hline Halobacillus halophilus & ATCC $35676^{\mathrm{T}}$ & X62174 \\
\hline Halobacillus litoralis & DSM $10405^{\mathrm{T}}$ & X94558 \\
\hline Marinococcus albus & DSM $20748^{\mathrm{T}}$ & X90834 \\
\hline Paenibacillus amylolyticus & NCIMB $8144^{\mathrm{T}}$ & X60606 \\
\hline Paenibacillus larvae & ATCC $9545^{\mathrm{T}}$ & X60619 \\
\hline Paenibacillus macerans & ATCC $8244^{\mathrm{T}}$ & X60624 \\
\hline Paenibacillus polymyxa & ATCC $842^{\mathrm{T}}$ & X60632 \\
\hline Sporosarcina ureae & NCIMB $9251^{\mathrm{T}}$ & X62174 \\
\hline Virgibacillus pantothenticus & ATCC $14576^{\mathrm{T}}$ & X60627 \\
\hline
\end{tabular}

* NCIMB, National Collection of Industrial and Marine Bacteria; ATCC, American Type Culture Collection; NCDO, National Collection of Dairy Organisms; DSM, Deutsche Sammlung von Mikroorganismen und Zellkulturen; NCFB, National Collection of Food Bacteria.

et al., 1982). Unless otherwise indicated, the tests were carried out in media containing $10 \%(\mathrm{w} / \mathrm{v})$ salts, at $\mathrm{pH} 7 \cdot 5$ and incubated at $37^{\circ} \mathrm{C}$.

Numerical analysis. Of the 117 phenotypic characteristics studied, 106 were differential features and used for numerical analysis. Positive and negative results were coded as 1 and 0 , respectively; non-compatible or missing data were coded as 9. Strain similarities were estimated with the Jaccard coefficient $\left(S_{\mathrm{J}}\right)$ (Jaccard, 1908) and cluster analysis was carried out by the unweighted pair group method with averages (UPGMA) (Sneath \& Johnson, 1972). Test error was estimated by examining 10 strains in duplicate (Sneath \& Johnson, 1972). Cophenetic correlation was also evaluated (Sneath \& Sokal, 1973). These computations were done using the NTSYS-pc version 1.80 program of Rohlf (1993) on a PC computer.

DNA extraction and purification. Cells from 18 representative strains selected for this study and 13 reference strains were harvested, washed, suspended in $0 \cdot 15 \mathrm{M} \mathrm{NaCl} / 0 \cdot 1 \mathrm{M}$ EDTA

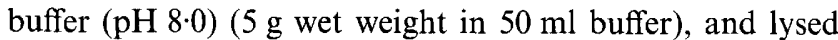
with lysozyme (approx. $10 \mathrm{mg}$ ) at $37^{\circ} \mathrm{C}$ and with SDS at a final concentration of $2 \%(\mathrm{w} / \mathrm{v})$ at $60^{\circ} \mathrm{C}$. The DNA was extracted and purified by the method of Marmur (1961). The purity was assessed from the $A_{260} / A_{280}$ and $A_{230} / A_{260}$ absorbance ratios (Johnson, 1994).

DNA base composition. The $\mathrm{G}+\mathrm{C}$ content of the DNA was determined from the midpoint value of the thermal denaturation profile (Marmur \& Doty, 1962) obtained with a model UV-Vis 551S spectrophotometer (Perkin-Elmer) at $260 \mathrm{~nm}$; this instrument was programmed for temperature increases of $1.0^{\circ} \mathrm{C} \mathrm{min}$. The $\mathrm{G}+\mathrm{C}$ content was calculated from the thermal denaturation temperature with the equation of Owen \& Hill (1979). The $G+C$ content of reference DNA from Escherichia coli NCTC 9001 was taken to be $51 \mathrm{~mol} \%$ (Owen \& Pitcher, 1985).

Preparation of ${ }^{3} \mathrm{H}$-labelled DNA and DNA-DNA hybridization experiments. DNA was radioactively labelled by the multiprime system with a commercial kit (RPN 1601Y; 


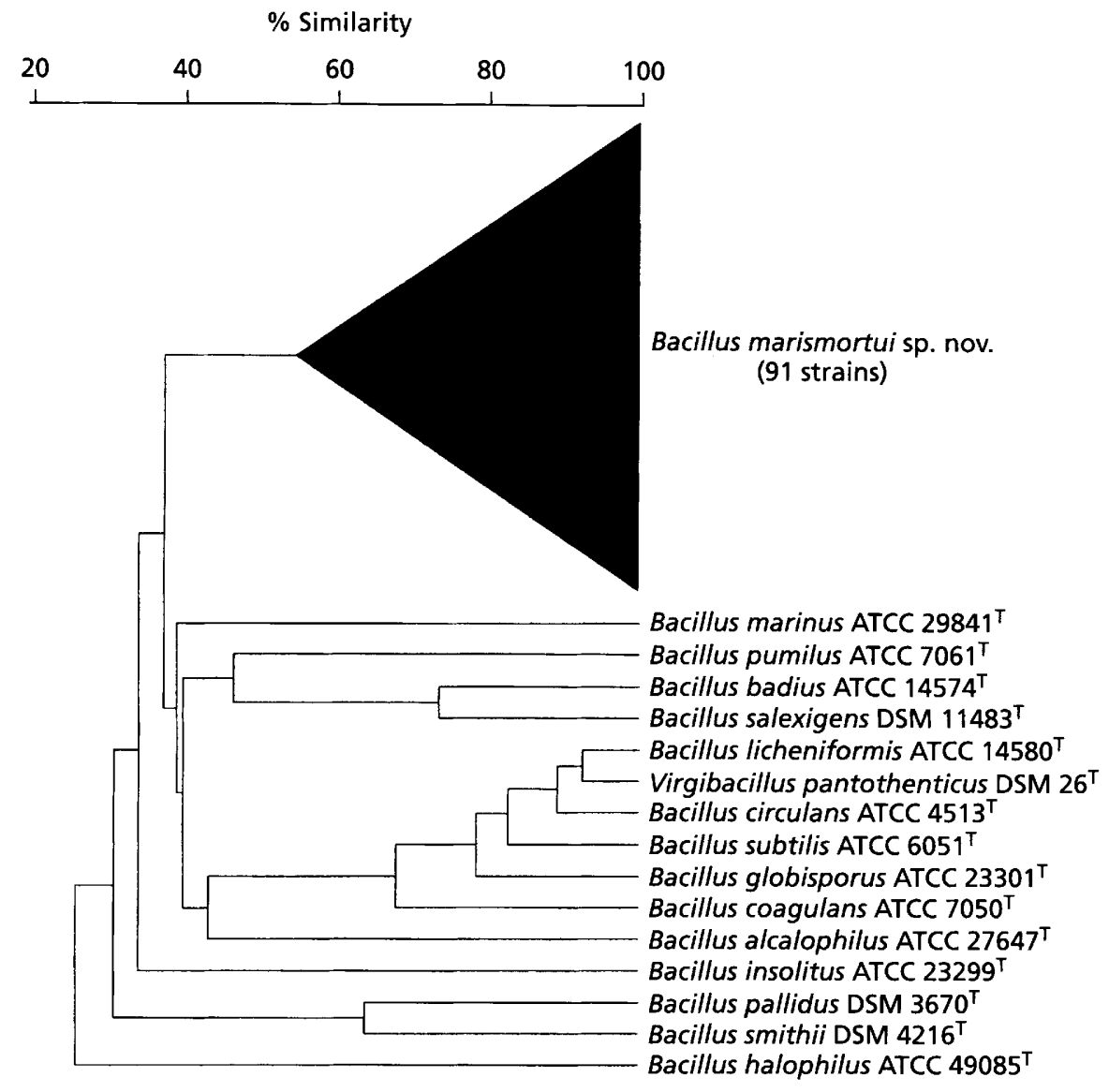

Fig. 1. Simplified dendrogram showing the clustering of the strains into a phenon based on $S$, coefficient and unweighted mean linkage clustering (UPGMA) for 91 moderately halophilic Gram-positive endospore-forming rods and 15 species belonging to Bacillus and Virgibacillus.

Amersham), using $\left[1^{\prime}, 2^{\prime}, 5-{ }^{3} \mathrm{H}\right] \mathrm{dCTP}$ (Amersham). The mean specific activity obtained with this procedure was $8.8 \times 10^{6}$ c.p.m. $(\mu \mathrm{g} \text { DNA })^{-1}$. The labelled DNA was denatured before hybridization by heating at $100^{\circ} \mathrm{C}$ for $5 \mathrm{~min}$ and then placed on ice. DNA-DNA similarity was studied by the competition procedure described by Johnson (1994). Competitor DNAs were sonicated (Braun Melsungen) at $50 \mathrm{~W}$ for two $15 \mathrm{~s}$ time intervals. Membrane filters (HAHY; Millipore) containing reference DNA (approx. $25 \mu \mathrm{g} \mathrm{cm}^{-2}$ ) were placed in $5 \mathrm{ml}$ screw-cap vials which contained the labelled, sheared, denatured DNA and the denatured and sheared competitor DNA. The ratio of the concentration of competitor DNA to the concentration of labelled DNA was at least $150: 1$. The final reaction concentrations were $2 \times$ SSC $(1 \times$ SSC is $0.15 \mathrm{M}$ sodium chloride plus $0.015 \mathrm{M}$ sodium citrate) and $30 \%$ formamide, and the final volume was $140 \mu \mathrm{l}$. The hybridization experiments were carried out under optimal conditions, with temperatures ranging between 45.3 and $47.5^{\circ} \mathrm{C}$, which is within the limits of validity for the filter method (De Ley \& Tijtgat, 1970). The vials were shaken slightly for $18 \mathrm{~h}$ in a water bath (Grant Instruments); these procedures were done in triplicate. After hybridization, the filters were measured with a liquid scintillation counter (Beckman Instruments) and the percentage similarity was calculated as described by Johnson (1994). At least two independent determinations were carried out for each experiment and the mean values are reported here.
Determination of isomers of diaminopimelic acid. The isomers of diaminopimelic acid in the cell walls of the 18 representative strains were detected by the method of Staneck \& Roberts (1974). Dried cells (approx. $10 \mathrm{mg}$ ) were hydrolysed with $1 \mathrm{ml} 10 \mathrm{M} \mathrm{HCl}$ at $100{ }^{\circ} \mathrm{C}$ for $20 \mathrm{~h}$ in a screwcap tube, and $1 \mathrm{ml}$ filtered hydrolysate was subjected to TLC on cellulose thin-layer (Merck) in parallel with a reference amino acid mixture. For separation, methanol/distilled water $/ 10 \mathrm{M} \mathrm{HCl}$ /pyridine $(80: 26: 4: 10$ by vol.) was used as the solvent. Then the chromatogram was dried at room temperature, sprayed with a $5 \%$ ninhydrin/butanol solution and heated at $100^{\circ} \mathrm{C}$ for $3 \mathrm{~min}$.

Phylogenetic analysis. Isolation of genomic DNA from strains $123^{\mathrm{T}}, 557$ and 832 , which were used as representatives of our isolates, in vitro amplification of the $16 \mathrm{~S}$ rRNA gene, and direct sequencing of the PCR-amplified 16S rDNA fragments were carried out using previously described methods (Springer et al., 1993).

Data analyses, including more than 4000 16S rRNA sequences available from rRNA sequence databases (Maidak et al., 1996; Van de Peer et al., 1994), were performed as described previously (Arahal et al., 1996). The most closely related sequences (Table 3 ) were chosen for constructing a similarity matrix; only those positions at which there were data for $90 \%$ of the $16 \mathrm{~S}$ rRNA sequences of the strains were used. The similarity matrix was corrected 
for multiple base changes at single positions by the method of Saitou \& Nei (1987).

\section{RESULTS}

\section{Reproducibility of phenotypic characters}

The inclusion of the pairs of randomly chosen duplicate strains in the analysis enabled experimental test error to be calculated. The mean probability of an erroneous result was $4.0 \%$. A small number of tests was responsible for most of the test error. These tests were hydrolysis of casein, acid production from arabinose and D-mannitol, utilization of citrate, sucrose, D-mannitol and butyrate as sole source of carbon and energy, and utilization of L-alanine and DL-arginine as sole source of carbon, nitrogen and energy.

\section{Numerical analysis}

The results of the numerical study of the strains grouped by means of the $S_{\mathrm{J}}$ coefficient and UPGMA clustering yielded the dendrogram shown in Fig. 1. The cophenetic correlation was 0.879 .

In the dendrogram obtained, all the isolates grouped in a single phenon at a $58 \%$ similarity level but none of the reference strains were included in that phenon. Table 2 shows the characteristics which differentiate the 91 isolates studied from one another. Other

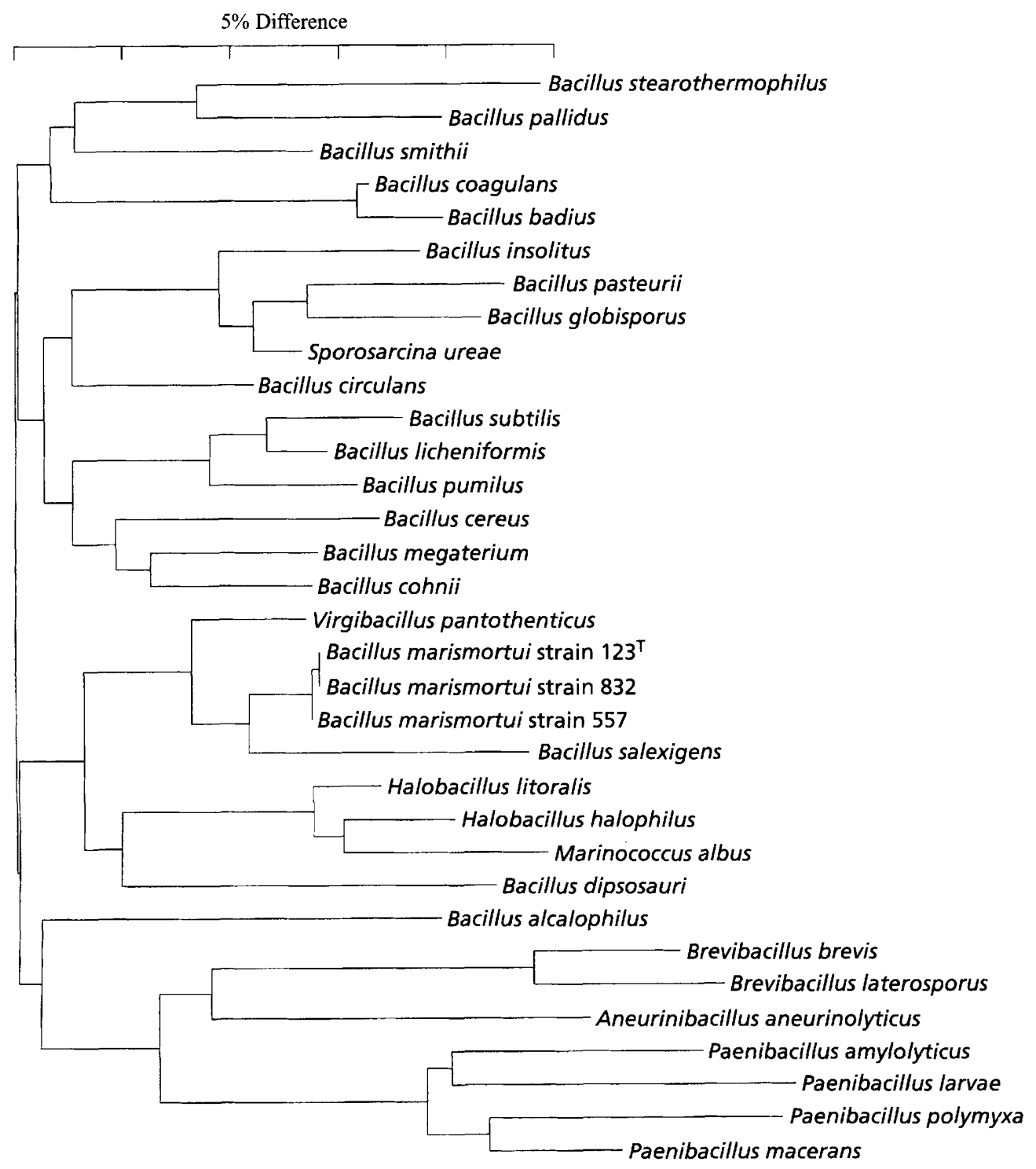

Fig. 2. Unrooted phylogenetic tree derived from the analysis of the 165 rRNA sequences of Bacillus marismortui strains $123^{\top}, 557$ and 832, some Bacillus species and other related species belonging to the Gram-positive bacteria with low DNA $\mathrm{G}+\mathrm{C}$ content branch. 
phenotypic characteristics are included below in the species description.

\section{DNA base composition}

The $\mathrm{G}+\mathrm{C}$ contents of the DNAs of 18 strains chosen as representative isolates were $39 \cdot 0-42 \cdot 8 \mathrm{~mol} \%$ (Table $1)$.

\section{DNA-DNA hybridization}

The results of the DNA-DNA hybridization experiments are shown in Table 1 . The levels of relatedness of labelled DNAs from three representative strains to DNAs from the other isolates were $70-100 \%$. On the other hand, low levels of relatedness $(0-45 \%)$ were found between the three reference strains and the other strains belonging to related species used for comparison.

\section{Determination of diaminopimelic acid in the cell wall}

The cell walls of 18 representative strains contained meso-diaminopimelic acid in the peptidoglycan.

\section{Phylogeny}

The almost complete 16S rRNA sequences (about 1560 bases) of strains $123^{\mathrm{T}}, 557$ and 832 were determined. These sequences were almost identical to each other $(99.9 \%)$. However, they did not show high similarity with other sequences available from the database of other bacterial species. The highest levels of similarity were with the $16 \mathrm{~S}$ rRNA sequence of $V$. pantothenticus $(97.8 \%), B$. salexigens $(96.6 \%)$, B. circulans $(95.9 \%)$, Halobacillus litoralis $(95.7 \%)$ and $B$. halophilus $(94 \cdot 6 \%)$.

The phylogenetic tree in Fig. 2 shows the relationship between our isolates and some representative Bacillus species and other related micro-organisms. The accession numbers for the 16S rRNA sequences of these reference strains are shown in Table 3. B. marismortui and $B$. salexigens are on the same phylogenetic branch, together with $V$. pantothenticus and close to H. litoralis, Halobacillus halophilus, Marinococcus albus and Bacillus dipsosauri.

\section{DISCUSSION}

All 91 Dead Sea isolates studied were grouped in a single phenon, indicating that they have very similar phenotypic characteristics (Table 2). On the other hand, these strains are quite different from the moderately halophilic Gram-positive rods described previously (Fendrich et al., 1990; Spring et al., 1996; Ventosa et al., 1989).

All strains are Gram-positive, motile, endosporeforming rods and strictly aerobic. On the basis of their phenotypic features, cell wall peptidoglycan (mesodiaminopimelic acid type) and DNA G + C contents, these strains can be considered as members of the genus Bacillus sensu lato (Claus \& Berkeley, 1986). Their salt requirements indicate that they should be included in the group of moderately halophilic bacteria, defined as those organisms able to grow optimally in media containing $5-15 \%(\mathrm{w} / \mathrm{v})$ salts (Kushner \& Kamekura, 1988).

Very recently, Heyndrickx et al. (1998) reported that Bacillus pantothenticus represents a phylogenetic group sufficiently different from other Bacillus species to warrant the status of a separate genus, for which they have proposed the name Virgibacillus, with the single species $V$. pantothenticus. This species can be distinguished from members of Bacillus rRNA group 1 (Bacillus sensu stricto) and from members of other aerobic endospore-forming bacteria by phenotypic characteristics. There are many phenotypic and genotypic differences between $V$. pantothenticus and our isolates (Table 4), for instance, their salt requirements (our isolates are unable to grow in media without $\mathrm{NaCl}$ ), growth in anaerobic conditions (achieved by $V$. pantothenticus but not by our isolates), and $\mathrm{G}+\mathrm{C}$ content, the values of our isolates $(39 \cdot 0-42 \cdot 8 \mathrm{~mol} \%)$ being somewhat higher than those of $V$.pantothenticus (36.9-38.3 mol \%) (Heyndrickx et al., 1998).

Phenotypically, our isolates were different in many characteristics with respect to the moderately halophilic species of the genus Bacillus, B. halophilus and $B$. salexigens (Ventosa et al., 1989; Garabito et al., 1997), and from moderately halophilic species of the genus Halobacillus, Halobacillus trueperi and $H$. litoralis (Spring et al., 1996) (Table 4).

The DNA base composition of our isolates (39.0$42.8 \mathrm{~mol} \%$ ) was similar to that of $H$. litoralis (42.0 mol \%) (Spring et al., 1996), but lower than the values described for $H$. trueperi $(43.0 \mathrm{~mol} \%$ ) (Spring et al., 1996) and B. halophilus $(51.5 \mathrm{~mol} \%$ ) (Ventosa et $a l ., 1989)$, and somewhat higher than those of $B$. salexigens (36.3-39.5 mol \%) (Garabito et al., 1997). Cell wall analysis of our strains showed that their peptidoglycan contained meso-diaminopimelic acid, as found in B. halophilus and B. salexigens (Ventosa et al., 1989; Garabito et al., 1997) as well as most other Bacillus species (Claus \& Berkeley, 1986), but which differed from the cell wall peptidoglycan (Orn-D-Asp type) described for H. trueperi and H. litoralis (Spring et al., 1996) (Table 4). Other traits which distinguish the strains studied from other related species are shown in Table 4.

The DNA relatedness experiments showed that our isolates form a single DNA similarity group with similarity values equal to or greater than $70 \%$. Most authors suggest that, among strains of the same species, the levels of DNA-DNA similarity should be equal to or greater than $70 \%$ (Owen \& Pitcher, 1985; Wayne et al., 1987; Stackebrandt \& Goebel, 1994). 
Table 4. Characteristics useful for distinguishing Bacillus marismortui from other related Gram-positive endospore-forming rods

Data from Claus \& Berkeley (1986), Garabito et al. (1997), Heyndrickx et al. (1998), Spring et al. (1996), Ventosa et al. (1989) and this study. 1, Bacillus marismortui; 2, Virgibacillus pantothenticus; 3, Bacillus halophilus; 4, Bacillus salexigens; 5, Halobacillus litoralis; and 6, Halobacillus trueperi. ND, Not determined; +, positive; - , negative.

\begin{tabular}{|c|c|c|c|c|c|c|}
\hline Character & 1 & 2 & 3 & 4 & 5 & 6 \\
\hline Pigmentation & Cream & Cream & None & None & Orange & Orange \\
\hline Spore shape* & E & $\mathrm{E} / \mathrm{S}$ & $\mathrm{E}$ & $\mathrm{E}$ & $\mathrm{E} / \mathrm{S}$ & $\mathrm{E} / \mathrm{S}$ \\
\hline Spore position* & $\mathrm{T} / \mathrm{ST}$ & $\mathrm{T}$ & $\mathrm{C}$ & $\mathrm{ST} / \mathrm{C}$ & $\mathrm{C} / \mathrm{ST}$ & $\mathrm{C} / \mathrm{ST}$ \\
\hline Sporangium swollen & + & + & - & + & ND & ND \\
\hline \multicolumn{7}{|l|}{ Growth in salts at $(\%, w / v)$ : } \\
\hline 0 & - & + & - & - & - & - \\
\hline 0.9 & - & + & - & - & + & + \\
\hline 3 & + & + & + & - & + & + \\
\hline 20 & + & - & + & + & + & + \\
\hline 25 & - & - & + & - & + & + \\
\hline 30 & - & - & + & - & - & + \\
\hline Optimal growth at $10 \%$ salts & + & - & - & + & + & + \\
\hline Growth at $50^{\circ} \mathrm{C}$ & + & + & + & - & - & - \\
\hline \multicolumn{7}{|l|}{ Growth at $\mathrm{pH}$ : } \\
\hline $8 \cdot 5$ & + & + & - & + & + & + \\
\hline $10 \cdot 0$ & - & + & - & + & - & - \\
\hline Anaerobic growth & - & + & - & - & - & - \\
\hline \multicolumn{7}{|l|}{ Hydrolysis of: } \\
\hline Casein & + & + & - & + & - & - \\
\hline Gelatin & + & + & - & + & + & + \\
\hline Starch & - & + & - & - & - & - \\
\hline Tween 80 & - & + & + & - & - & - \\
\hline Phosphatase & + & - & - & - & - & - \\
\hline \multicolumn{7}{|l|}{ Acid production from: } \\
\hline D-Fructose & + & + & - & + & + & + \\
\hline D-Galactose & - & + & - & - & - & + \\
\hline Maltose & + & + & - & + & + & + \\
\hline D-Mannose & - & + & + & + & ND & $\mathrm{ND}$ \\
\hline Sucrose & - & + & + & ND & + & + \\
\hline D-Trehalose & - & + & + & - & + & + \\
\hline D-Xylose & - & - & + & - & + & - \\
\hline Methyl red & + & - & - & - & ND & ND \\
\hline Nitrate reduction & + & + & - & - & - & - \\
\hline $\mathrm{H}_{2} \mathrm{~S}$ production & + & - & - & + & ND & ND \\
\hline Arginine dehydrolase & - & + & - & - & - & - \\
\hline Urease & + & - & + & ND & - & - \\
\hline Cell wall type $\dagger$ & $m$-Dpm & $m-\mathrm{Dpm}$ & $m$-Dpm & $m$-Dpm & $\begin{array}{c}\text { Orn-D- } \\
\text { Asp }\end{array}$ & $\begin{array}{c}\text { Orn-D- } \\
\text { Asp }\end{array}$ \\
\hline $\mathrm{G}+\mathrm{C}$ content $(\mathrm{mol} \%)$ & $40 \cdot 7$ & 36.9 & $51 \cdot 5$ & $39 \cdot 5$ & $42 \cdot 0$ & $43 \cdot 0$ \\
\hline
\end{tabular}

* E, Ellipsoidal; S, spherical; C, central; ST, subterminal; T, terminal.

$\uparrow m$-Dpm, meso-Diaminopimelic acid.

Thus, on the basis of DNA relatedness data, our isolates form a group of organisms that are sufficiently related as to constitute a genospecies. On the other hand, low levels of DNA-DNA similarity, with values of $0-45 \%$, were obtained between the three representative strains and all the moderately halophilic, marine or non-halophilic bacteria studied (Table 1).
According to the comparative analysis of the $16 \mathrm{~S}$ rRNA sequences, strains $123^{\mathrm{T}}, 557$ and 832 show a close phylogenetic relationship and are included in the phylogenetic group containing the low $\mathrm{G}+\mathrm{C}$ content Gram-positive bacteria, closely related to the species belonging to phylogenetic group I of the genus Bacillus (Fig. 2) described by Ash et al. (1991). The recently 


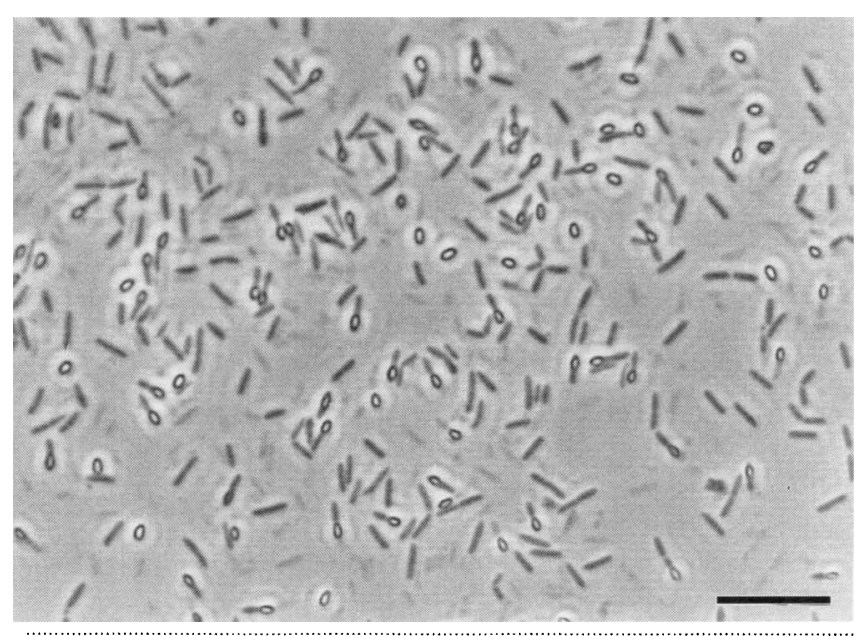

Fig. 3. Phase-contrast micrograph of strain $123^{\top}$ showing sporeforming rods. Bar, $10 \mu \mathrm{m}$.

described moderately halophilic species $B$. salexigens (Garabito et al., 1997) is also phylogenetically close to our isolates. The higher levels of sequence similarity between strains $123^{\mathrm{T}}, 557$ and 832 and the species included in the phylogenetic analysis correspond to those of $V$. pantothenticus $(97.8 \%$ similarity) and $B$. salexigens $(96.6 \%$ similarity). The rest of the $16 \mathrm{~S}$ rRNA similarity values obtained were lower than $96 \%$. Stackebrandt \& Goebel (1994) stated that levels of similarity between $16 \mathrm{~S}$ rRNA sequences that are lower than $97 \%$ suggest that strains do not belong to the same species; therefore our isolates can be considered a different species to $B$. salexigens.

These results agree with the DNA-DNA similarity studies and overall, they show that our isolates should be classified in a new species. Although $16 \mathrm{~S}$ rRNA sequence comparison shows that they are most closely related to $V$. pantothenticus, they do not match with the description of the newly proposed genus Virgibacillus and thus, it is proposed that they are placed in the genus Bacillus as Bacillus marismortui. Other molecular data should be compiled in order to elucidate the taxonomic position of this and other Bacillus species, including $B$. salexigens.

\section{Description of Bacillus marismortui Arahal, Márquez, Volcani, Schleifer and Ventosa sp. nov.}

Bacillus marismortui (ma.ris.mor'tu.i. L. gen. n. maris of the sea; L. adj. mortuus dead; M.L. gen. n. marismortui of the Dead Sea).

Gram-positive rods, $2 \cdot 0-3.6$ by $0.5-0.7 \mu \mathrm{m}$, occurring singly, in pairs or in short chains (Fig. 3). Motile, oval endospores are produced at a terminal or subterminal position in swollen sporangia. Colonies are pigmented (cream), circular, opaque and entire. Growth occurs at $5-25 \%(\mathrm{w} / \mathrm{v})$ total salts, optimal growth at $10 \%$ $(\mathrm{w} / \mathrm{v})$. No growth occurs in the absence of salts. Grows at $15-50{ }^{\circ} \mathrm{C}$ (optimal at $37^{\circ} \mathrm{C}$ ) and at $\mathrm{pH} 6 \cdot 0-9 \cdot 0$ (optimal at $\mathrm{pH} 7 \cdot 5$ ). Strictly aerobic. Catalase and oxidase are produced. Acid is produced from Dfructose, D-glucose, glycerol and maltose; acid is not produced from D-arabinose, D-galactose, lactose, Dmannitol, sucrose, D-trehalose or D-xylose. Casein, DNA and gelatin are hydrolysed; starch or Tween 80 are not hydrolysed. Methyl red test is positive. Nitrate but not nitrite is reduced. Indole, Voges-Proskauer and Simmons citrate tests are negative. Urease is produced; $\mathrm{H}_{2} \mathrm{~S}$, arginine dehydrolase or phenylalanine deaminase are not produced. The following compounds are utilized as sole carbon and energy sources: D-fructose, inulin, maltose, D-mannitol, D-mannose, pyruvate, D-raffinose, D-rhamnose and succinate. Susceptible to chloramphenicol, erythromycin, penicillin $\mathrm{G}$, streptomycin and tetracycline; resistant to nalidixic acid, neomycin, novobiocin and rifampin. Other phenotypic features of this species are shown in Table 2. DNA G $+\mathrm{C}$ content is $39 \cdot 0-42.8 \mathrm{~mol} \%\left(T_{\mathrm{m}}\right.$ method). The cell wall contains peptidoglycan of the meso-diaminopimelic acid type. Isolated from the Dead Sea. The type strain is strain $123^{\mathrm{T}}$ (= DSM $12325^{\mathrm{T}}=$ ATCC $700626^{\mathrm{T}}=\mathrm{CIP} \quad 105609^{\mathrm{T}}=$ CECT $5066^{\mathrm{T}}$ ).

Description of the type strain. The description of the type strain is the same as that of the species, except that the type strain grows at $3-20 \%(\mathrm{w} / \mathrm{v})$ total salt and pH $6 \cdot 0-8 \cdot 5$. The DNA G $+\mathrm{C}$ content is $40 \cdot 7 \mathrm{~mol} \%$ ( $T_{\mathrm{m}}$ method). Other characteristics of this strain are shown in Table 2.

\section{ACKNOWLEDGEMENTS}

This article is dedicated to the memory of Professor B. E. Volcani, who died on 6 February 1999 from kidney failure. He pioneered studies on halophilic micro-organisms and described new halobacteria and moderately halophilic bacteria. In 1936 he reported the presence of a variety of microorganisms in the Dead Sea, a hypersaline environment previously considered to be sterile due to its high salinity. His early studies on the Dead Sea were recently continued, since some of old samples from the 1930s were preserved by Professor Volcani.

David R. Arahal was a recipient of a fellowship from the Ministerio de Educación y Ciencia, Spain. This investigation was supported by Grants from the Biotech Program of the European Commission (Generic Project Biotechnology of Extremophiles, grant BIO2-CT93-0274, and Extremophiles as Cell Factories, grant BIO4-CT96-0488), from the Ministerio de Educación y Ciencia, Spain (grant PB-930920), and from the Junta de Andalucía.

\section{REFERENCES}

Arahal, D. R., Dewhirst, F. E., Paster, B. J., Volcani, B. E. \& Ventosa, A. (1996). Phylogenetic analyses of some extremely halophilic archaea isolated from Dead Sea water, determined on the basis of their 16S rRNA sequences. Appl Environ Microbiol 62, 3779-3786.

Ash, C., Farrow, A. E., Allbanks, S. \& Collins, M. D. (1991). Phylogenetic heterogeneity of the genus Bacillus revealed by small-subunit-ribosomal RNA sequences. Lett Appl Microbiol 13, 202-206. 
Claus, D. \& Berkeley, R. C. W. (1986). Genus Bacillus Cohn 1872. In Bergey's Manual of Systematic Bacteriology, vol. 2, pp. 1105-1139. Edited by P. H. A. Sneath, N. S. Mair, M. E. Sharpe \& J. G. Holt. Baltimore: Williams \& Wilkins.

De Ley, J. \& Tijtgat, R. (1970). Evaluation of membrane filter methods for DNA-DNA hybridization. Antonie Leeuwenhoek 36, 461-474.

Fahmy, F., Flossdorf, J. \& Claus, D. (1985). The DNA base composition of the strains of the genus Bacillus. Syst Appl Microbiol 6, 60-65.

Fendrich, C., Hippe, H. \& Gottschalk, G. (1990). Clostridium halophilum $\mathrm{sp}$. nov. and $C$. litorale $\mathrm{sp}$. nov., an obligate halophilic and a marine species degrading betaine in the Stickland reaction. Arch Microbiol 154, 127-132.

Garabito, M. J., Arahal, D. R., Mellado, E., Márquez, M. C. \& Ventosa, A. (1997). Bacillus salexigens sp. nov., a new moderately halophilic Bacillus species. Int J Syst Bacteriol 47, 735-741.

García, M. T., Ventosa, A., Ruiz-Berraquero, F. \& Kocur, M. (1987). Taxonomic study and amended description of Vibrio costicola. Int J Syst Bacteriol 37, 251-256.

Heyndrickx, M., Lebbe, L., Kersters, K., De Vos, P., Forsyth, G. \& Logan, N. A. (1998). Virgibacillus: a new genus to accommodate Bacillus pantothenticus (Proom and Knight 1950). Emended description of Virgibacillus pantothenticus. Int J Syst Bacteriol 48, 99-106.

Jaccard, P. (1908). Nouvelles recherches sur la distribution florale. Bull Soc Vaudoise Sci Nat 44, 223-270.

Javor, B. (1989). Dead Sea. In Hypersaline Environments Microbiology and Biogeochemistry, pp. 282-291. Berlin: Springer.

Johnson, J. L. (1994). Similarity analysis of DNAs. In Methods for General and Molecular Bacteriology, pp. 655-681. Edited by P. Gerhardt. Washington, DC: American Society for Microbiology.

Kushner, D. J. \& Kamekura, M. (1988). Physiology of halophilic eubacteria. In Halophilic Bacteria, vol. I, pp. 109-140. Edited by F. Rodríguez-Valera. Boca Raton, FL: CRC Press.

Maidak, B. L., Olsen, G. J., Larsen, N., Overbeek, R., McCaughey, M. J. \& Woese, C. R. (1996). The Ribosomal Database Project (RDP). Nucleic Acids Res 24, 82-85.

Marmur, J. (1961). A procedure for the isolation of deoxyribonucleic acid from micro-organisms. $J$ Mol Biol 3, 208-218.

Marmur, J. \& Doty, P. (1962). Determination of the base composition of deoxyribonucleic acid from its thermal denaturation temperature. $J$ Mol Biol 5, 109-118.

Nieto, J. J., Fernández-Castillo, R., Márquez, M. C., Ventosa, A., Quesada, E. \& Ruiz-Berraquero, F. (1989). Survey of metal tolerance in moderately halophilic eubacteria. Appl Environ Microbiol 55, 2385-2390.

Oren, A. (1988). The microbial ecology of the Dead Sea. In Advances in Microbial Ecology, vol. 10, pp. 193-229. Edited by K. C. Marshall. New York: Plenum.

Oren, A. (1993). Ecology of extremely halophilic microorganisms. In The Biology of Halophilic Bacteria, pp. 25-53. Edited by R. H. Vreeland \& L. I. Hochstein. Boca Raton, FL: CRC Press

Owen, R. J. \& Hill, L. R. (1979). The estimation of base compositions, base pairing and genome sizes of bacterial deoxyribonucleic acids. In Identification Methods for Microbiologists, 2nd edn, pp. 217-296. Edited by F. A. Skinner \& D. W. Lovelock. London: Academic Press.

Owen, R. J. \& Pitcher, D. (1985). Current methods for estimating DNA base composition and levels of DNA-DNA hybridization. In Chemical Methods in Bacterial Systematics, pp. 67-93. Edited by M. Goodfellow \& E. Minnikin. London: Academic Press.

Quesada, E., Ventosa, A., Ruiz-Berraquero, F. \& RamosCormenzana, A. (1984). Deleya halophila, a new species of moderately halophilic bacteria. Int J Syst Bacteriol 40, 261-267.

Rohlf, F. J. (1993). NTSYS-pc. Numerical Taxonomy and Multivariate Analysis System, version 1.80. New York: Exeter Software.

Saitou, N. \& Nei, M. (1987). The neighbor-joining method: a new method for reconstructing phylogenetic trees. Mol Biol Evol 4, $406-425$.

Sneath, P. H. A. \& Johnson, R. (1972). The influence on numerical taxonomy similarities of errors in microbiological tests. $J$ Gen Microbiol 72, 377-392.

Sneath, P. H. A. \& Sokal, R. R. (1973). Numerical Taxonomy. The Principles and Practice of Numerical Classification. San Francisco: W. H. Freeman.

Spring, S., Ludwig, W., Márquez, M. C., Ventosa, A. \& Schleifer, K.-H. (1996). Halobacillus gen. nov., with descriptions of Halobacillus litoralis sp. nov. and Halobacillus trueperi sp. nov., and transfer of Sporosarcina halophila to Halobacillus halophilus comb. nov. Int J Syst Bacteriol 46, 492-496.

Springer, N., Ludwig, W., Amann, R., Schmidt, H. J., Görtz, H. D. \& Schleifer, K.-H. (1993). Occurrence of fragmented 16S rRNA in an obligate bacterial endosymbiont of Paramecium caudatum. Proc Natl Acad Sci USA 90, 9892-9895.

Stackebrandt, E. \& Goebel, B. M. (1994). Taxonomic note: a place for DNA-DNA reassociation and 16S rRNA sequence analysis in the present species definition in bacteriology. Int $J$ Syst Bacteriol 44, 846-849.

Staneck, J. L. \& Roberts, G. D. (1974). Simplified approach to identification of aerobic actinomycetes by thin-layer chromatography. Appl Microbiol 28, 226-231.

Van de Peer, Y., Van den Broeck, I., De Rijk, P. \& De Wachter, R. (1994). Database on the structure of small ribosomal subunit RNA. Nucleic Acids Res 22, 3488-3494.

Ventosa, A., Quesada, E., Rodríguez-Valera, F., Ruiz-Berraquero, F. \& Ramos-Cormenzana, A. (1982). Numerical taxonomy of moderately halophilic Gram-negative rods. J Gen Microbiol 128, 1959-1968.

Ventosa, A., García, M. T., Kamekura, K., Onishi, H. \& RuizBerraquero, F. (1989). Bacillus halophilus sp. nov., a moderately halophilic Bacillus species. Syst Appl Microbiol 12, 162-166.

Ventosa, A., Arahal, D. R. \& Volcani, B. E. (1999). Studies on the microbiota of the Dead Sea - 50 years later. In Microbiology and Biogeochemistry of Hypersaline Environments, pp. 139-147. Edited by A. Oren. Boca Raton, FL: CRC Press.

Volcani, B. E. (Wilkansky, B.) (1936). Life in the Dead Sea. Nature 138, 467.

Volcani, B. E. (Elazari-Volcani, B.) (1940). Studies on the Microflora of the Dead Sea. PhD thesis, Jerusalem Hebrew University.

Wayne, L. G., Brenner, D. J., Colwell, R. R. \& 9 other authors (1987). International Committee on Systematic Bacteriology. Report of the ad hoc committee on reconciliation of approaches to bacterial systematics. Int J Syst Bacteriol 37, 463-464. 